\title{
The Impact of Task-Based Language Teaching on the Development of Iranian EFL Learners' ESP Reading Comprehension Skills
}

\author{
Mahnam Setayesh (Corresponding Author) \\ Department of Foreign Languages, Sepidan Branch, Islamic Azad University, Sepidan, Iran \\ E-mail: mahnam_56@yahoo.com \\ Amin Marzban \\ Department of Foreign Languages, Sepidan Branch, Islamic Azad University, Sepidan, Iran \\ E-mail: marzban@iausepidan.ac.ir
}

Doi:10.7575/aiac.alls.v.8n.2p.70

URL: http://dx.doi.org/10.7575/aiac.alls.v.8n.2p.70
Received: 12/02/2017

Accepted: 05/04/2017

\begin{abstract}
The present study primarily aimed at investigating the effect of Task-Based Language Teaching (TBLT) on development of the Iranian EFL learners' ESP Reading Comprehension Skills. Moreover, it was aimed at investigating the probable difference between the TBLT-instructed students of Law and Mechanical Engineering with respect to their ESP reading skills, on the one hand, and the probable difference between TBLT-instructed males and females, on the other. In so doing, four groups of 25 participants (including two experimental groups and two control ones) were selected through cluster random sampling from among ESP students majoring in Law and Mechanical Engineering. After a four-week instruction treatment, the post-test was conducted to the participants. The results of the data analysis revealed that the experimental groups significantly performed better than the control groups in the post-test with respect to their reading comprehension scores. Furthermore, the results of independent samples t-test indicated that TBLT has been more effective on the Mechanical Engineering students than the Law students. Finally, the findings of the study were indicative of the fact that TBLT was more effective on females' reading comprehension rather than on males'. Consequently, it can be concluded that TBLT can have a positive effect on students' ESP reading ability. The findings of this study can be employed in different areas of second/foreign language teaching and learning to facilitate and improve the process of language learning.
\end{abstract}

Keywords: task-based language teaching (TBLT), English for specific purposes (ESP), EFL learners, reading comprehension

\section{Introduction}

From the early 1960s, English for Specific Purposes (ESP) has been a standout amongst the most conspicuous educational patterns. ESP has been defined as "an approach to language teaching in which all decisions as to content and method are based on the learner's reason for learning" (Hutchinson \& Waters, 1987, p.19). The growing need to use the English language for the expression of information within specific professional fields in the past decades is undeniable. In response to this need, the teaching and learning of ESP has become a major concern mainly in countries where English is taught as a foreign language.

The mastery of English for Specific Purposes can include different skills (reading, writing, speaking, listening) and components (structure, lexicon); however, the significance of the reading component has been highlighted in the recent years (Dreyer \& Nel, 2003). The level of reading comprehension required for academic reading, especially in the context of ESP, is more complex than any other reading types and purposes. Reading is one of the skills which can be one of the most significant sources of gaining technical knowledge which has occupied a noticeable part of ESP books.

Academic texts in ESP courses are usually approached through traditional methods of language teaching, especially the Grammar Translation Method (GTM). Generally speaking, in this method, mother tongue is used as a medium of teaching. More specifically, mother tongue is used to elaborate on conceptual difficulties and to explain different grammatical structures which may be boring. Albeit GTM has over the years had a remarkable success, it suffers from a number of serious shortcomings. First, overemphasis on translation can never free the learners from reliance on their mother tongue. Second, even if language learners know a great deal of grammatical rules, it does not guarantee that they can use such rules in authentic communicative situations. Third, in GTM, the texts are mostly taken form literary works rather than the authentic texts. As a result, the language learned frequently does not meet the authentic needs of the language learners and finally, remembering grammatical rules and bilingual lexical lists does not provoke students to interactively communicate in the target language (Larsen-Freeman \& Anderson, 2000; Brown, 2007). Due to the 
aforementioned problems and shortcomings, the present study aims at investigating the probable effect of Task-Based approach on teaching micro-skills to the Iranian EFL learners in the context of ESP with a focus on their reading comprehension performance. To be more specific, the research questions of the present study are formulated as:

1. Is there any difference between ESP reading comprehension skills of EFL learners who are instructed via taskbased language teaching (TBLT) methodology and those thought by Grammar Translation Method (GTM)?

2. Is there any difference between ESP reading comprehension skills of students of Law and Mechanical Engineering who have been instructed via task-based language methodology?

3. Is there any difference between ESP reading comprehension skills of male and female Iranian EFL learners instructed via task-based language methodology?

The present study is of significance due to the fact that it can illuminate the probable effect of Task-Based method on teaching micro-skills to the Iranian EFL learners in the context of ESP with a focus on their reading comprehension performance and thus provides useful information for both language teachers and learners. Further, the results of this study can be utilized for improving and revising language teaching methodologies as well as language testing materials. Moreover, it can provide insights into material development and thus facilitate the process of learning different language skills, particularly reading, for the learners. Finally, this study can help teachers and mostly students to understand these findings and use them to improve the quality of second/ foreign language learning and teaching.

\section{Literature Review}

\subsection{Reading Comprehension}

The ultimate objective of reading is Comprehension (Nation, 2005; Spear-Swerling, 2006). More specifically, it involves making explicit what is implicit in a sentence or in a situation (Schank, 1982). Comprehension is "a result of, or accompanied by, a set of fundamental procedures or principles" (Smith, 1994, p. 11). These procedures or principles include cognitive structures, which work as a summary of the reader's past experience that categorizes everything the reader knows about the world and works as the premise of all his/her understanding and comprehension of the world. Understanding spoken and written language is included in those cognitive structures. In fact, comprehension and prediction are related due to the fact that prediction means raising questions while comprehension means being able to provide answers for some of these questions.

Reading cannot be isolated from thinking since reading is a form of thought that is concentrated on or stimulated by written text. The mentioned principles provide three implications concerning reading: "(a) reading needs to be fast due to the fact that the brain must move ahead quickly to avoid becoming bogged down by the visual details of the text, (b) the brain directs eyes to select the visual information in the text and where to move next, (c) and reading depends on non-visual information" (Smith, 1994, p. 14). In order to help students effectively achieve reading comprehension skill, a teacher needs to take four important issues into account which include "allowing sufficient time for authentic text reading, teacher's guiding students to focus on text understanding, providing students with opportunities for peer and collaborative learning, and giving students chance to talk to their teacher and one another about their replies to reading" (Fielding \& Pearson, 1994, p. 10). Reading comprehension can be achieved when meaning is constructed out of text (Goodman, Watson, \& Burke, 1996). The meaning is based on information tied to the reader's objective for reading, which is then combined with existing knowledge and linguistic schema. This schema is used for language production and comprehension (Goodman, 2003; Weaver, 1988).

\subsection{Rationale for Employing TBLT to Teach Reading Skills}

According to the researchers' definition, "reading comprehension is the process of simultaneously eliciting and creating meaning through interaction with written language" (Doff, 1998, p. 24). In order to emphasize both the significance and the insufficiency of the text as a determinant of reading comprehension, researchers use the terms extracting and constructing meaning (Doff, 1998). Nonetheless, most people learn to read in their native language without any trouble. However, some children and adults need additional help in this regard. Yet, there may be others who learn to read a second, third or additional language, with or without having learned to read in their first language. Reading instruction needs to consider different types of language learners as well as their needs. Findings of previous research studies have indicated that there is a great deal of transfer from learning to read in one language to learning to read in a second language (Grabe, 2004).

So as to acquire the respective target language effectively, especially in children, language learners need to involve actively in processing the meanings of whatever they hear and read. In this regard, a variety of tasks can be designed to provoke learners and give them an objective for processing the meaning and achieving a desired product (Willis, 1996). Unlike grammar exercises that are focused directly on the structure and comprehension questions that may seem tedious and senseless, TBLT provides language learners with both a framework of structures, forms and/or words to be used and a good reason for doing the activities. Thus, "task-based reading activities may prove to be a good means of integrating the four language skills and fostering effective language learning because such activities are done with the aim of comprehending something, achieving a conclusion or forming a whole picture of something within a pre-set frame" (Nunan, 1989, p. 21). It should be noted that although such activities are used to improve the learners reading skill, they are expected to help improve the other language skills as well (Nunan, 1989).

\subsection{Empirical Studies on the Integration of Reading and TBLT}

During the last decade, many studies have investigated the incorporation of TBLT into the reading instruction. This 
section is a review of these studies. Some studies indicated the superiority of TBLT over the traditional reading instruction approach. For instance, in an EFL context, Tilfarlioglu and Basaran (2007) tried to investigate the effect of Task-based writing activities on students' reading comprehension ability. To this end, they two groups of 28 students were included in their study. A pre-test and a post-test were administered on both groups. The results of their study indicated that Task-based writing activities can enhance reading comprehension ability of English language learners.

Investigating task-based reading contribution to the reading comprehension development of the Iranian EFL learners, Golchin and Kheirabadi (2013) conducted a study in which 60 female advanced EFL learners (selected from among a pool of 100 learners) were assigned equally and randomly into two groups of thirty, consisting of an experimental and a control group. Both groups received a pretest and a post-test of reading. The results of their study clearly indicated the development of the experimental group's reading comprehension ability through application of task-based reading activities.

Kolaei, Yarahmadi, and Maghsoudi (2013) attempted to scrutinize the efficiency of task-based instruction in promoting the Iranian EFL students' reading comprehension ability. According to the results of their study, the performance of both experimental and control groups in the post-test was considerably higher than that of their performance in the pre-test. The results also showed that there was no statistically significant difference between the two methods. Therefore, in their study, both task-based approach and traditional method promoted the learners' reading comprehension.

In a study conducted by Shabani and Ghasemi (2014), the effect of Task-Based Language Teaching on reading comprehension of the ESP learners was investigated. In their study, there were two groups of thirty participants: a control group (CBLT) and an experimental group (TBLT). After conducting the study, the respective data analysis revealed that the subjects in TBLT group performed better on the reading comprehension post-test than the CBLT group, which means that TBLT has been more effective than CBLT in teaching reading comprehension to Iranian ESP learners.

In another Study, Chalak (2015) investigated the probable development of reading comprehension ability through Taskbased Instruction (TBI). The participants of her study were elected out of the Iranian high school students. The results of her study showed that the students in the experimental group outperformed the control group. Furthermore, the findings revealed that employing interactive tasks in English classes can promote the EFL learners' reading comprehension ability.

ÖKCÜ (2015) explored the effects of Task Based Instruction (TBI) on the EFL learners' reading comprehension. To conduct the study, both experimental and control groups were included. After conducting the respective procedures, the findings of the study revealed that both experimental and control groups showed an improvement with respect to their reading comprehension. However, there was a statistically significant difference between the mean scores of the experimental group and those of the control group with respect to their reading comprehension. More specifically, the experimental group was more successful in the post-test.

Although these studies have informed us with the possible benefits of TBLT in reading comprehension instruction, there are some gaps in the literature which are attempted to be filled in this study. While the previous studies had focused on general English reading courses, this study attempts to investigate the extent to which TBLT and Grammar Translation Methods can improve the reading ability of students in ESP courses. Furthermore, the present study aims at examining the probable effects of the mentioned teaching approaches on the reading ability of the students majoring in the fields of Law and Mechanical Engineering. The last objective of this study deals with the examination of the mediating variable of gender on the effect of instruction types on the students' reading ability.

\section{Method}

\subsection{Participants}

The participants of the study included the Iranian university students majoring in BA programs of Law and Mechanical Engineering who were taking EAP courses related to their field of study for one session per week in a 17-week semester. The total population (that is the available population) included 286 students who aged between 19 and 25 $($ mean $=22.57)$ and their native language was Persian. Both male and female students participated in this study. Accordingly, a number of 100 ESP learners were selected through cluster random sampling out of 8 Law and Mechanical Engineering ESP classes at three State, Azad and Payam-e Noor universities in Shiraz and Marvdasht. The treatments were assigned to different classes randomly.

The control groups included a Law group (C1) and a Mechanical Engineering group (C2) and each group included 25 students. In the same way, the experimental groups consisted of a Law group (E1) and a Mechanical Engineering group of the same proportion of students (each with 25 participants). In order to harmonize and balance both groups with respect to the number of participants, the number of students in each group was determined to be the same so as to prevent from the probable effect of the intervening factor of the heterogeneity of the number of participants. Then the mentioned two pairs of experimental and control groups underwent a pretest and posttest. It is noteworthy that all of the subjects agreed to participate in this study.

\subsection{Instruments}

In order to assess the reading comprehension ability of the ESP students, the 'ESP Reading Comprehension Test' adopted from ESP books and ESP Reading comprehension section of MA University Entrance Exam specific for the students of Law and Mechanical Engineering was used at the beginning and at the end of the treatment as the pre- and post-tests. The reading texts were extracted from a combination of university ESP course books published by SAMT 
Publications and ESP Reading comprehension section of MA University Entrance Exam specific for the students of Law and Mechanical Engineering (Jalalipour, 2015; Shiravi, 2015).

\subsection{Procedures}

As a treatment, task-based instruction was utilized in the two experimental groups. As a placebo, traditional instruction, that is, Grammar Translation Method (GTM), was used in the control groups. Due to the fact that the main objective of the present study has been to investigate the effects of task-based activities on reading comprehension, control groups received no task-based instruction. In control groups, teacher made students read the text. They studied text by translating some sentences and afterwards they were given reading comprehension questions. In experimental groups, the respective lesson started with a task which the students were supposed to work on so as to achieve an aim. Then, they were given the same reading text given to control groups to see how well they did. In fact, they had a purpose to read the text. After conscious rising activities, these groups were also given the same reading comprehension questions. The procedure of treatment took an intensive course of four weeks.

\section{Data Analysis and Results}

\subsection{Research Question One}

The first research question addressed the difference between ESP reading comprehension skills of those Iranian EFL learners who are instructed through task-based language teaching (TBLT) methodology and those of the EFL learners who are taught through Grammar Translation Method (GTM).

In order to answer this question, the reading comprehension ability scores of the participants of the TBLT and GTM groups in the pre-test and post-test were compared. Table 1 indicates the mean scores of the pre-test as well as the result of t-test for these scores.

Table 1. Mean Score differences in pre- and post-test TBLT and GTM groups

\begin{tabular}{cc|cccc}
\hline & Mean scores (SD) & $\mathrm{t}$ & $\mathrm{df}$ & Sig (2-tailed) & Mean difference \\
\hline Law GTM & $24.36(7.51)$ & 5.237 & 48 & .070 & 2.011 \\
\hline Mechanics GTM & $27.12(7.49)$ & 5.237 & 48 & .070 & 2.011 \\
\hline Law TBLT & $28.96(6.82)$ & & & & \\
\hline Mechanics TBLT & $26.32(7.43)$ & & & & \\
\hline
\end{tabular}

As indicated in table 1, the difference between the mean scores of the GTM and TBLT were not significantly different $(t=5.23, p<.05)$. It states that the participants of the present study were of the same reading ability at the beginning of the study. The following table indicates the results of the post-test.

Table 2. Post-test results

\begin{tabular}{cc|cccc}
\hline & Mean scores (SD) & $\mathrm{t}$ & $\mathrm{df}$ & Sig (2-tailed) & Mean difference \\
\hline Law GTM & $25.75(8.76)$ & 8.564 & 48 & .000 & 10.55 \\
\hline Mechanics GTM & $26.73(6.45)$ & & & & 10.55 \\
\hline Law TBLT & $32.54(7.43)$ & & & & \\
\hline Mechanics TBLT & $36.59(7.86)$ & & & & \\
\hline
\end{tabular}

As indicated in Table 2, the mean scores of the GTM groups and TBLT groups were significantly different $(\mathrm{t}=8.56$, $\mathrm{p}<.05$ ). These findings indicate that the students of the TBLT group were of higher scores than their counterparts in the GTM group. This finding suggests that the TBLT instruction was more successful in improving students' reading ESP ability.

\subsection{Research Question Two}

The second question aimed to address the difference between ESP reading comprehension skills of students of Law and Mechanical Engineering who have been instructed through task-based language methodology?

In order to answer this question, a set of independent t-test were run which are reported in Table 3, below. 
Table 3. Independent samples t-test for law and mechanical engineering majors and their reading comprehension ability

\begin{tabular}{|c|c|c|c|c|c|c|c|c|c|}
\hline & & \multicolumn{3}{|c|}{$\begin{array}{l}\text { Levene's } \\
\text { Test for } \\
\text { Equality of } \\
\text { Variances }\end{array}$} & \multicolumn{5}{|c|}{ t-test for Equality of Means } \\
\hline & & $\mathrm{F}$ & & Sig. & $\mathrm{t}$ & $\mathrm{df}$ & $\begin{array}{c}\text { Sig. } \\
\text { (2-tailed) }\end{array}$ & $\begin{array}{c}\text { Mean } \\
\text { Difference }\end{array}$ & $\begin{array}{l}\text { Std. Error } \\
\text { Difference }\end{array}$ \\
\hline & $\begin{array}{l}\text { Equal variances } \\
\text { assumed }\end{array}$ & & 2.364 & .082 & 6.268 & 48 & .000 & 4.682 & .573 \\
\hline \multirow[t]{2}{*}{ Law } & $\begin{array}{l}\text { Equal } \\
\text { variances } \\
\text { not } \\
\text { assumed }\end{array}$ & & & & 6.268 & 49 & .000 & 4.682 & .573 \\
\hline & $\begin{array}{l}\text { Equal variances } \\
\text { assumed }\end{array}$ & & .128 & .736 & 7.958 & 48 & .000 & 8.567 & .739 \\
\hline $\begin{array}{l}\text { Mechanical } \\
\text { Engineering }\end{array}$ & $\begin{array}{l}\text { Equal } \\
\text { variances } \\
\text { not } \\
\text { assumed }\end{array}$ & & & & 7.958 & 49 & .000 & 8.567 & .739 \\
\hline
\end{tabular}

As it is shown in Table 3, with respect to the field of Law, the observed ratio of 6.2 is greater than the expected one at the .05 level $(\mathrm{P}<0.5)$, which means that the difference between the pretest scores and posttest scores of reading comprehension ability of the students of Law is greater than the value required to reject the null hypothesis at the .05 level of significance $(\mathrm{P}<0.5)$. Furthermore, the mean difference is 4.68 which shows that this difference is statistically significant.

Moreover, with respect to the field of Mechanical Engineering, the observed ratio of 7.9 is greater than the expected one at the .05 level $(\mathrm{P}<0.5)$, which means that the difference between the pretest scores and posttest scores of reading comprehension ability of the students of Law is greater than the value required to reject the null hypothesis at the .05 level of significance $(\mathrm{P}<0.5)$. Furthermore, the mean difference is 8.56 which shows that this difference is statistically significant.

\subsection{Research Question Three}

The third question addressed the difference between ESP reading comprehension skills of male and female Iranian EFL learners instructed by a task-based language methodology.

In order to answer the present research question, the mean scores of the male and female students in the both control and experimental groups were computed and compared. Table 4 reveals the descriptive statistics of the post-test scores of female and male student.

Table 4. Descriptive statistics related to males and females of experimental groups in posttest

\begin{tabular}{lccccc}
\hline & N & Minimum & Maximum & Mean & Standard Deviation \\
Law (Males) & 15 & 9 & 29 & 23.56 & 6.42 \\
Law (Females) & 10 & 11 & 38 & 32.81 & 3.56 \\
Mechanical Eng. (Males) & 13 & 12 & 32 & 25.38 & 5.49 \\
Mechanical Eng. (Females) & 12 & 15 & 39 & 37.42 & 6.72 \\
\hline
\end{tabular}

This table reveals that the mean scores of the female engineering and female law students were the highest $(37.42 \&$ $32.81)$ and the lowest score belonged to the male law students ( $23.56 \& 25.38)$. Table 5 below, is an indicative of the comparison of female and male students' scores. 
Table 5. Independent samples t-test for males and females and their reading comprehension ability

\begin{tabular}{|c|c|c|c|c|c|c|c|c|}
\hline & & \multicolumn{2}{|c|}{$\begin{array}{l}\text { Levene's } \\
\text { Test for } \\
\text { Equality of } \\
\text { Variances }\end{array}$} & \multicolumn{5}{|c|}{ t-test for Equality of Means } \\
\hline & & $\mathrm{F}$ & Sig. & $\mathrm{t}$ & $\mathrm{df}$ & $\begin{array}{c}\text { Sig. } \\
\text { (2-tailed) }\end{array}$ & $\begin{array}{c}\text { Mean } \\
\text { Difference }\end{array}$ & $\begin{array}{l}\text { Std. Error } \\
\text { Difference }\end{array}$ \\
\hline & $\begin{array}{l}\text { Equal variances } \\
\text { assumed }\end{array}$ & 1.840 & .083 & 6.423 & 47 & .000 & 8.592 & .581 \\
\hline Males & $\begin{array}{l}\text { Equal } \\
\text { variances } \\
\text { not } \\
\text { assumed }\end{array}$ & & & 6.423 & 49 & .000 & 8.592 & .581 \\
\hline & $\begin{array}{l}\text { Equal variances } \\
\text { assumed }\end{array}$ & .137 & .832 & 9.257 & 47 & .000 & 11.674 & .863 \\
\hline Females & $\begin{array}{l}\text { Equal } \\
\text { variances } \\
\text { not } \\
\text { assumed }\end{array}$ & & & 9.257 & 49 & .000 & 11.674 & .863 \\
\hline
\end{tabular}

As shown in Table 5, with respect to the Males, the observed ratio of 6.4 is greater than the expected one at the .05 level, which means that the difference between the pretest scores and posttest scores of reading comprehension ability of the male participants in both experimental groups is greater than the value required to reject the null hypothesis at the .05 level of significance. Moreover, the mean difference is 8.59 which shows that this difference is statistically significant.

Furthermore, with respect to the field of Females, the observed ratio of 9.2 is greater than the expected one at the .05 level, which means that the difference between the pretest scores and posttest scores of reading comprehension ability of the female participants in both experimental groups is greater than the value required to reject the null hypothesis at the .05 level of significance. Moreover, the mean difference is 11.67 which shows that this difference between Males and Females with respect to their reading comprehension scores is statistically significant.

\section{Discussion and Conclusions}

The findings of the present study indicated that the task-based language teaching of reading comprehension in an EAP context was more successful than the effect of the traditional GTM instruction of reading. The superiority of TBLT over the traditional, translation-based approaches to teaching reading has been reported by previous studies (Chalak, 2015; Golchin \& Kheirabadi, 2013; Mohammadipour \& Rashid, 2015; ÖKCÜ, 2015; Tilfarlioglu \& Basaran, 2007; Shabani \& Ghasemi, 2014) which is supported by the findings of the present study. The results of the present study also indicated that the engineering students benefited more from TBLT approach to teaching reading in comparison to their counterparts in the law group. The last finding of this study revealed that the female students benefited from the TBLT instruction significantly more than the male students.

Regarding the practicality of the study, the researcher of this study chose to limit the scope of the context under investigation merely to reading comprehension ability rather than to all main skills of language learning including listening, speaking and writing. Moreover, it was limited to the Iranian university EFL learners from three State, Azad and Payam-e Noor universities in Shiraz as well as Islamic Azad University of Marvdasht. The range of the participants' age was also limited to 19-25. Additionally, the students selected as the participants of the study were merely limited to those who were studying either in the field of Law or Mechanical Engineering. These limitations led to focus on a narrower area and thus reach more precise and more scientific results.

With reference to what was discussed in the previous sections, the main purpose of this study was to investigate the effect of TBLT on ESP reading comprehension. Additionally, it aimed at investigating the difference between TBLTinstructed males and females with respect to their reading comprehension. Finally, it aimed at investigating the difference between the students of the fields of Law and Mechanical Engineering with respect to their reading comprehension. The aggregated results regarding the abovementioned research questions of this study, however, need to be investigated in other contexts in order to assess their authenticity and practicality.

In what follows, a few subjects will be enumerated as the potential issues of investigation in the area of the effect of TBLT on second/foreign language learning skills: the effect of TBLT on the Iranian EFL learners' speaking ability, the effect of TBLT on the Iranian EFL learners' listening comprehension, the effect of task-based reading comprehension on the Iranian EFL learners' ESP courses, the effect of TBLT on the Iranian EFL learners' vocabulary recall and learning, the effect of TBLT on the Iranian EFL learners' grammar ability, the effect of TBLT on the Iranian EFL learners' writing ability, and the effect of TBLT on the Iranian EFL teachers' teaching achievement level. 
Acknowledgements

I would like to declare my sincere thanks to Mr. Mohammad Zamani who helped with the statistical analysis of this study and facilitated my way through providing me with valuable guidance in this regard.

\section{References}

Brown, H. D. (2007). Teaching by Principles: An interactive approach to language pedagogy (3rd Ed.). Englewood Cliffs, NJ: Prentice Hall Regents.

Chalak, A. (2015). The effects of explicit and implicit pragmatic instruction on Iranian EFL learners' production of suggestion speech act in the context of distance learning. Journal of Applied Linguistics and Language Research, 2(4), 275-284.

Doff, A. (1998). Teach English: A training course for teacher. London: Cambridge University Press.

Dreyer, C. \& Nel, C. (2003). Teaching reading strategies and reading comprehension within a technology-enhanced learning environment. System, 2(31), 349-365.

Fielding, L., \& Pearson, P. D. (1994). Reading comprehension: What works. Educational Leadership, 51(5), 62-67.

Golchin, V. F., \& Kheirabadi, M. D. (2013). Enhancing reading comprehension of Iranian advanced EFL learners through task-based reading activities. International Journal of Applied Linguistics \& English Literature, 2(5), 23-37.

Goodman, K. S. (2003). The reading process. In A. D. Flurkey \& J. Xu (Eds.), On the revolution of reading: The selected writings of Kenneth S. Goodman (pp. 94-104). Portsmouth, NH: Heinemann.

Goodman, Y. M., Watson, D. J., \& Burke, C. L. (1996). Reading miscue inventory: Alternative procedures. Katonah, NY: Richard C. Owen.

Grabe, W. (2004). Research on teaching reading. Annual Review of Applied Linguistics, 2(24), 44-69.

Hutchinson, T., \& Waters, A. (1987). English for specific purposes: A learning centered approach. Cambridge University Press. Cambridge.

Jalalipour, J. (2015). English for students of mechanical engineering: Thermal Approach. Tehran: SAMT Publications.

Kolaei, N. N., Yarahmadi, M., \& Maghsoudi, M. (2013). The effect of task-based approach on Iranian EFL learner's reading comprehension ability. Indian Journal of Fundamental and Applied Life Sciences, 3(3), 404-416.

Larsen-Freeman, D., \& Anderson, M. (2000). Techniques and principles in language teaching (3rd Eds.). Oxford: Oxford University Press.

Mohammadipour, M. \& MD. Rashid, S. (2015). The impact of task-based instruction program on fostering ESL learners' speaking ability: A cognitive approach. Advances in Language and Literary Studies, 6(2), 113-126.

Nation, I. S. P. (2005). Vocabulary learning through extensive reading. In G. Poedjosoedarmo (Eds.), Innovative approaches to reading and writing (pp. 10-21). Singapore: RELC Anthology Series.

Nunan, D. (1989). Syllabus design. Oxford: Oxford University Press.

ÖKCÜ, D. (2015). Effects of task-based instruction on reading comprehension of Turkish EFL learners. International Journal of English Language Teaching, 3(2), 23-37.

Schank, R. C. (1982). Reading and understanding. Hillsdale, NJ: Erlbaum.

Shabani, M. B., \& Ghasemi, A. (2014). The effect of task-based language teaching (TBLT) and content-based language teaching (CBLT) on the Iranian intermediate ESP learners' reading comprehension. Social and Behavioral Sciences, 98, 1713-1721. doi:10.1016/j.sbspro.2014.03.598

Shiravi, A. H. (2015). Legal texts I: Contract law. Tehran: SAMT Publications.

Smith, M. W. (1994). Metaphors in English education: Putting things in perspective. English Education, 26(3), 157176.

Spear-Swerling, L. (2006). Children's reading comprehension and oral reading fluency in easy text. Reading and Writing, 19, 199-220.

Tilfarlioglu, F. Y., \& Basaran, S. (2007). Enhancing reading comprehension through task-based writing activities: An experimental study. The Reading Matrix, 7(3), 134-152.

Weaver, J. L. (1988). Reconsidering a balanced approach to reading. Oxford: Oxford University Press.

Willis, J. (1996). A framework for task-based learning. Harlow: Longman. 